\title{
PENTINGNYA PERAWAT MELAKUKAN PERENCANAAN KEPERAWATAN UNTUK MENINGKATKAN MUTU ASUHAN KEPERAWATAN
}

\author{
Maranti Syah
}

\section{Email: marantisyah555@gmail.com}

\begin{abstract}
ABSTRAK
Latar Belakang: Perencanaan keperawatan merupakan suatu rencana tindakan keperawatan yang dilaksanakan oleh perawat kepada klien dengan tujuan untuk mecapai kesejahteraan kesehatan klien dan kemandirian klien menjaga kesehatannya. Pada tahap ini perawat menciptakan rencana tindakan keperawatan untuk mengatasi masalah dan meningkatkan kesehatan klien, yang dimana kita ketahui perencanaan keperawatan adalah salah satu bagian dari asuhan keperawatan,yang terbagi atas pengkajian keperawatan,diagnosa keperawatan, perencanaan keperawatan,implementasi keperawatan.dan evaluasi keperawatan. Asuhan keperawatan ialah suatu cara agar pemecahan masalah yang memampukan perawat supaya mengatur dan memberikan asuhan keperawatan. Manajemen keperawatan mempunyai lima fungsi utama, yakni perencanaan, pengorganisasian, pengaturan staf, pengarahan, serta pengendalian aktivitas unit keperawatan. Metode: Metode yang digunakan ialah menggunakan literature review. Hasil: Perawat mengetahui bahwa pentingnya melakukan perencanaan keperawatan untuk meningkatkan mutu asuhan keperawatan.
\end{abstract}

\section{Kata Kunci: Perawat, Perencanaan Keperawatan, Asuhan Keperawatan.}

\section{LATAR BELAKANG}

Keperawatan adalah bagian integral yang tidak dapat terpisahkan dari upaya pelayanan kesehatan secara universal. Keperawatan juga merupakan suatu bentuk pelayanan profesional yang bersifat humanistik, menggunakan pendekatan holistik, dilakukan berdasarkan ilmu dan kiat keperawatan, berorientasi kepada kebutuhan objektif klien.
Rumah Sakit merupakan tempat rujukan medis dan kesehatan serta merupakan institusi yang padat ilmu, padat modal, padat karya serta padat teknologi, tempat berbagai profesi bekerja sama, seharusnya menjadi pusat informasi bagi pasien serta masyarakat pada umumnya, sekaligus bagi pusat kesehatan sendiri (Departemen Kesehatan RI, 1997). 
Perencanaan keperawatan merupakan suatu susunan kegiatan penentuan langkah-langkah pemecahan masalah dan prioritasnya, perumusan tujuan, rencana tindakan dan penilaian asuhan keperawatan pada pasien atau klien berdasarkan dari analisis data dan diagnosa keperawatan. Tujuan dari perencanaan keperawatan ialah untuk mecapai kesejahteraan kesehatan klien dan kemandirian klien dalam menjaga kesehatannya.

Perencanaan asuhan keperawatan merupakan pedoman dari continuity of care. Dokumentasi perencanaan asuhan keperawatan yang tidak saling berhubungan dalam rekam medis berdampak pada kualitas asuhan pasien.

Salah satu pelayanan kesehatan yang diberikan oleh tenaga kesehatan ialah pelayanan keperawatan, sebagai bagian dari pelayanan kesehatan, maka pelayanan keperawatan yang dikerjakan oleh tenaga perawat memiliki tugas diataranya memberikan asuhan keperawatan (Hidayat, 2011, p.75).

Asuhan keperawatan merupakan suatu pendekatan untuk pemecahan masalah yang menjadikan perawat untuk mengatur dan memberikan asuhan keperawatan. Standar asuhan yang tercantum dalam Standar Praktik Klinis Keperawatan terdiri dari lima fase asuhan keperawatan yaitu: 1) Pengkajian 2) Diagnosa 3) Perencanaan; 4) Implementasi dan 5) Evaluasi. Salah satu manfaat dari penerapan asuhan keperawatan yang baik ialah meningkatkan mutu dan kualitas pelayanan kesehatan terutama dalam bidang keperawatan (Kozier, 2010).

Menurut Sumijatun (2010, p.88) permasalahan pelayanan keperawatan di Indonesia ialah masih banyaknya perawat yang belum melakukan asuhan keperawatan yang sesuai dengan standar yang telah ditentukan. Di sebagian besar tatanan pelayanan keperawatan, masih terbatas melakukan kegiatan-kegiatan yang belum memenuhi kaedah atau standar asuhan keperawatan secara profesional yang bertanggung gugat.

Kepuasan pasien ialah perasaan yang dimiliki oleh pasien dan timbul sebagai hasil dari kinerja layanan kesehatan setelah pasien membandingkannya dengan apa yang diharapkan (Pohan, 2007). Hasil tersebut merupakan respon dari pasien terhadap pelayanan kesehatan yang diterima secara nyata.

Pelayanan keperawatan merupakan bagian integral dari pelayanan kesehatan yang memegang peranan penting dalam menentukan mutu pelayanan Rumah Sakit, dalam mencapai tujuan 
pembangunan kesehatan karena pelayanan keperawatan diberikan secara terusmenerus selama 24 jam serta berada dalam berbagai tatanan pelayanan kesehatan. Berdasarkan hal diatas pelayanan keperawatan mempunyai peranan yang cukup besar agar mewujudkan terlaksananya programprogram yang telah ditetapkan oleh menteri kesehatan.

Kualitas asuhan keperawatan bisa mendeskripsikan keberhasilan dari sebuah Rumah Sakit dalam memberikan pelayanan kesehatan dan hal ini bergantung kepada pengelolaan sumber daya manusia guna mencapai visi, misi, serta tujuan dari organisasi. Manajemen sumber daya manusia menjadi keputusan yang strategis dalam sebuah rumah sakit organisasi. Tujuan organisasi yang ingin dicapai membutuhkan peran seorang manajer yang berkualitas dalam mengelolah sumber daya manusia yang dimiliki oleh rumah sakit.

Keadaan kurangnya kepuasan pasien terjadi dikarenakan oleh tuntutan kebutuhan pasien yang semakin meningkat namun tidak diiringi dengan perbaikan tindakan perawat (Momon Sudarma, 2008). Layanan keperawatan dan kepuasan pasien menjadi acuan keberhasilan penyelenggaraan pelayanan kesehatan di puskesmas. Kepuasan pasien akan terpenuhi bila adanya pelayanan yang diberikan telah sesuai dengan harapan mereka. Apabila pelayanan yang diberikan belum sesuai dengan apa yang diharapkan oleh pasien maka pasien akan merasa tidak puas (Tjiptono, 2001). Perawat harus mampu memberikan pelayanan keperawatan yang optimal sesuai dengan standar pelayanan keperawatan yang telah ditetapkan. Hal tersebut dikarenakan kepuasan pasien adalah indikator utama keberhasilan pelayanan keperawatan.

Dengan adanya sebuah perencanaan maka sesuatu tersebut kemungkinan besar sesuai dengan sasaran ataupun kebutuhan. Sama halnya dengan dunia keperawatan, agar layanan kesehatan yang diberikan dapat berkualitas dengan baik maka diperlukan perencanaan keperawatan sehingga tindakan yang dilakukan sesuai dengan kebutuhan pasien.

\section{METODE}

Metode yang digunakan ialah menggunakan literature review. Metode ini menganalisis, mengeksplorasi dan kajian bebas pada artikel, jurnal, text book, maupun e-book yang relevan dan berfokus pada metode pembelajaran klinik yang mempengaruhi pengetahuan perawat terkait dengan sasaran keselamatan pasien 
Literatur review ialah penjelasan tentang teori, temuan, serta bahan penelitian lain yang didapatkan dari bahan acuan untuk dijadikan sebagai acuan kegiatan penelitian untuk menyusun kerangka pemikiran yang jelas dari perumusan masalah yang ingin di teliti. Metode ini memberikan gambaran mengenai bagaimana tentang perencanaan asuhan keperawatan.

\section{HASIL}

Perawat mempunyai pengetahuan tentang sasaran keselamatan pasien di rumah sakit dan perawat mampu menerapkan sasaran keselamatan pasien tersebut. Perencanaan keperawatan dapat menghasilkan penerapan keperawatan yang tepat karena sudah mempunyai pedoman rencana tindakan yang ingin diimplementasikan kepada klien.

Salah satu indikator dari mutu pelayanan keperawatan itu ialah apakah pelayanan keperawatan yang diberikan itu memuaskan atau tidak memuaskan. Kepuasan adalah suatu tingkat perasaan pasien yang timbul sebagai akibat dari kinerja layanan yang di perolehnya setelah pasien membandingkannya dengan apa yang diharapkannya. Kepuasan pasien merupakan salah satu komponen utama atau penting.
Bahwa tahap perencanaan bertujuan pada memprioritaskan masalah, merumuskan tujuan dan kriteria hasil, membuat intruksi keperawatan, dan mendokumentasikan rencana asuhan keperawatan. Dalam menentukan tahap perencaan bagi perawat diperlukan berbagai pengetahuan dan keterampilan.

\section{PEMBAHASAN}

Perawat merupakan sebagai salah satu profesi yang merupakan bagian dari tim kesehatan yang bertanggung jawab membantu klien atau pasien dalam kondisi sehat maupun sakit (Haryanto, 2007). Sumbangan yang diberikan oleh perawat ialah melalui pelaksanaan proses keperawatan. Proses keperawatan merupakan kerangka berpikir yang digunakan oleh perawat untuk melaksanakan fungsi dan tanggung jawabnya secara mandiri.

Asuhan keperawatan merupakan faktor penting dalam kelangsungan hidup pasien dan aspek-aspek pemeliharaan, rehabilitatif dan prefentif perawatan kesehatannya. Menurut Shore, untuk sampai pada hal ini, profesi keperawatan telah menelaah proses pemecahan masalah yang menggabungkan elemen yang paling diinginkan dari segi keperawatan dengan elemen yang paling relevan dari sistem teori, dengan menggunakan metode 
ilmiah. Proses keperawatan ini kemukakan pada tahun 1950-an sebagai proses yang terdiri atas dari tiga tahap yaitu : Pengkajian, perencanaan dan evaluasi yang didasarkan pada metode ilmiah pengamatan, pengukuran, pengumpulan data dan penganalisaan temuan.

Proses asuhan keperawatan adalah tugas dan kewajiban seorang perawat dari pasien datang sampai pasien pulang, dimulai dengan melakukan pengkajian secara menyeluruh, kemudian menegakkan diagnosa keperawatan dari data pengkajian tersebut, serta melaksanakan intervensi, implementasi dan evaluasi keefektifan diagnosa awal yang sudah ditegakkan (Nursalam, 2007).

Perencanaan keperawatan ialah rencana tindakan keperawatan yang dilakukan oleh perawat kepada klien atau pasien yang bertujuan untuk mecapai kesejahteraan kesehatan klien dan kemandirian klien menjaga kesehatannya. Perencanaan keperawatan ialah suatu susunan kegiatan penentuan langkah-langkah pemecahan masalah dan prioritasnya, perumusan tujuan, rencana tindakan dan penilaian asuhan keperawatan pada pasien/klien berdasarkan analisis data dan diagnosa keperawatan (Dinarti \& yuli mulyanti , 2017).
Perencanaan ini ialah suatu petunjuk tertulis yang menggambarkan secara tepat rencana tindakan keperawatan yang dilakukan kepada klien sesuai dengan kebutuhannya berdasarkan diagnosa keperawatan.

Tahapan perencanaan dapat diartikan sebagai inti atau pokok dari proses keperawatan dikarenakan perencanaan merupakan keputusan awal yang memberi arah bagi tujuan yang ingin dicapai, hal yang akan dilakukan, termasuk bagaimana, kapan, dan siapa yang akan melakukan tindakan keperawatan. Dikarenakan, dalam menyusun rencana tindakan keperawatan untuk klien, keluarga dan orang terdekat perlu dilibatkan secara maksimal.

Tahapan perencanaan ini memiliki beberapa tujuan penting yaitu, diantaranya sebagai alat komunikasi antara sesama perawat dan tim kesehatan lainnya, meningkatkan kesinambungan asuhan keperawatan bagi klien, serta mendokumentasikan proses dan kriteria hasil asuhan keperawatan yang ingin dicapai.

\section{Tahapan Perencanaan Keperawatan:}

\section{Penentuan Prioritas Diagnosis}

$\begin{array}{lrr}\text { Penetapan } & \text { prioritas } & \text { merupakan } \\ \text { penyusunan } & \text { urutan } & \text { diagnosis }\end{array}$ keperawatan atau masalah klien dengan 
menggunakan tingkat kedaruratan atau kepentingan untuk memperoleh tahapan intervensi keperawatan yang dibutuhkan (Henry dan Walker, 2004). Penenentuan prioritas diagnosis ini dilakukan dalam tahap perencanaan setelah tahap diagnosis keperawatan. Dengan menentukan diagnosis keperawatan, maka dapat dilihat diagnosis mana yang akan dilakukan atau diatasi pertama kali atau yang segera dilakukan.

Berdasarkan tingkat kegawatan (mengancam jiwa): 1)Prioritas tinggi : Prioritas tinggi mencerminkan situasi yang mnengancam kehidupan (nyawa seseorang) sehingga perlu dilakukan tindakan terlebih dahulu seperti masalah bersihan jalan nafas. 2) Prioritas sedang : Prioritas ini menggambarkan situasi yang tidak gawat dan tidak mengancam hidup klien seperti masalah higiene perseorangan. 3)Prioritas rendah: Prioritas rendah ini menggambarkan situasi yang tidak berhubungan langsung dengan prognosis dari suatu penyakit yang secara spesifik seperti masalah keuangn atau lainnya.

\section{Menentukan Tujuan dan Kriteria}

\section{Hasil (outcome).}

Membuat tujuan yaitu membuat standar atau ukuran yang dapat digunakan untuk melakukan evaluasi terhadap perkembangan pasien dan keterampilan dalam merawat pasien. Tujuan keperawatan yang baik ialah pernyataan yang menjelaskan suatu tindakan yang dapat diukur berdasarkan kemampuan dan kewenangan perawat. Dikarenakan kriteria hasil dari diagnosa keperawatan mewakili status dari kesehatan pasien yang dapat dicapai atau dipertahankan melalui rencana tindakan keperawatan yang mandiri, sehingga dapat menghasilkan perbedaan antara diagnosa keperawatan dan masalah kolaboratif. Hasil dari diagnosa keperawatan tidak dapat untuk membantu mengevaluasi efektivitas dari intervensi keperawatan jika tindakan medis juga diperlukan.

\section{Rencana Tindakan Keperawatan (nursing order)}

Rencana tindakan yang akan diberikan pada pasien dituliskan secara terinci, jelas dan dapat di ukur. Rencana perawatan dibuat selaras dengan rencana medis sehingga saling melengkapi untuk meningkatkan status kesehatan pasien. Dalam merumuskan rencana tindakan yang perlu diperhatikan ialah: 1)Rencana tindakan keperawatan ialah desain spesifik 
intervensi yang membantu klien mencapai kriteria hasil 2) Dokumentasi rencana tindakan yang telah dilaksanakan harus ditulis dalam sebuah format agar dapat membantu perawat untuk memproses informasi yang didapatkan selama tahap pengkajian dan diagnosa keperawatan 3)Perencanaan bersifat individual sesuai dengan kondisi dan kebutuhan pasien. 4)Bekerjasama dengan pasien dalam merencanakan intervensi keperawatan

Tujuan perencanaan intervensi keperawatan dan aktivitas keperawatan ialah untuk mengurangi, menghilangkan, dan mencegah masalah keperawatan klien. Kriteria proses perawatan membuat rencana tindakan asuhan keperawatan untuk mengatasi masalah yang terjadi dan meningkatkan kesehatan meliputi perencanaan terdiri dari prioritas, tujuan dan rencana tindakan keperawatan, bekerjasama dengan klien dalam menyusun rencana tindakan keperawatan, perencanaan bersifat individual sesuai dengan kondisi atau kebutuhan klien, mendokumentasikan rencana keperawatan.

\section{PENUTUP}

Keperawatan adalah bagian integral yang tidak dapat terpisahkan dari upaya pelayanan kesehatan secara universal.
Perawat mempunyai pengetahuan tentang sasaran keselamatan pasien di rumah sakit dan perawat mampu menerapkan sasaran keselamatan pasien tersebut. Perencanaan keperawatan dapat menghasilkan penerapan keperawatan yang tepat karena sudah mempunyai pedoman rencana tindakan yang ingin diimplementasikan kepada klien.

\section{REFRENSI}

Astar. Dkk. ( 2018). Pengaruh Pelayanan Asuhan Keperawatan Terhadap Kepuasan Pasien Di Puskesmas Takalala Kabupaten Soppeng. Journal Of Management. 1(2). 3357.

Budiono. Pertami, S. B. (2016). Konsep Dasar Keperawatan. Jakarta: Bumi Medika.

Bumulo, M. I. Dkk. (2017). Pengaruh Manajemen Model Asuhan Keperawatan Profesional Tim Terhadap Kualitas Pelayanan Keperawatan Di Bangsal Pria Rsud Datoe Binangkang Kabupaten Bolaang Mongondow. Jurnal Keperawatan. 5(2):2 - 3.

Butar-Butar, J., \& Simamora, R. H. (2016). Hubungan Mutu Pelayanan Keperawatan dengan Tingkat Kepuasan Pasien Rawat Inap di 
RSUD Pandan Kabupaten Tapanuli

Tengah. Jurnal Ners Indonesia, 6(1), 50-63.

Cristhina, P. Dkk. (2019). Analisis Ketidaksinambungan Dokumentasi Perencanaan Asuhan Keperawatan : Metode Ishikawa. Jurnal Ilmiah Kesehatan (JIK). 12(2):518-524.

Gunawan. Dkk. (2017). Hubungan Antara Pengetahuan Dengan Kinerja Perawat Dalam Melaksanakan Asuhan Keperawatan Di Ruang Rawat Inap Rumah Sakit Tingkat Ii Dr. Soepraoen Malang. Nursing News. 2(2). 195-205.

Kasim. Dkk. (2016). Peningkatan Kualitas Pelayanan Dan Pendokumentasian Asuhan Keperawatan Dengan Metode Tim. Nurseline journal. 1(1):62-72.

Simamora, R. H. (2005). Hubungan Persepsi Perawat Pelaksana Terhadap Penerapan Fungsi Pengorganisasian Yang Dilakukan Oleh Kepala Ruangan Dengan Kinerjanya Diruang Rawat Inap RSUD Koja Jakarta Utara (Doctoral dissertation, Tesis FIK UI, Tidak dipublikasikan).

Supratti. Ashriady. (2016). Pendokumentasian Standar Asuhan
Keperawatan Di Rumah Sakit Umum Daerah Mamuju, Indonesia. 2(1):44-51.

Ulumiyah, N. H. (2018) Meningkatkan Mutu Pelayanan Kesehatan Dengan Penerapan Upaya Keselamatan Pasien Di Puskesmas. Jurnal Administrasi Kesehatan Indonesia. 6(2):150 - 151.

Wulandini, P. Dkk. (2016). Faktor-Faktor Yang Berhubungan Dengan Pendokumentasian Asuhan Keperawatan Di Rumah Sakit Jiwa. Ners Jurnal Keperawatan. 12(2):131-142.

Zendrato, M.V., Hariyati, T.S., (2017) Optimalisasi Pengelolaan Asuhan Keperawatan Di Instalasi Rawat Jalan Rumah Sakit X. Jurnal Persatuan Perawat Indonesia. 2(2):86-87 . 
